\title{
Geotechnical Behavior of Eastern Senegal Rock Mass Slopes by Geomechanical Classifications and Applications
}

\author{
Déthié Sarr1', Mathioro Fall1, Oustasse A. Sall1, Papa Malick Ngom², Yves Berthaud ${ }^{3}$ \\ ${ }^{1}$ UFR of Engineering Sciences, University of Thiès, Thiès, Senegal \\ ${ }^{2}$ Department of Geology, University Cheikh Anta Diop of Dakar, Dakar, Senegal \\ ${ }^{3}$ Faculty of Engineering, University Pierre et Marie Curie, Paris, France \\ Email: dethie.sarr@univ-thies.sn
}

How to cite this paper: Sarr, D., Fall, M., Sall, O.A., Ngom, P.M. and Berthaud, Y. (2018) Geotechnical Behavior of Eastern Senegal Rock Mass Slopes by Geomechanical Classifications and Applications. Journal of Geoscience and Environment Protection, 6, 11-24.

https://doi.org/10.4236/gep.2018.65002

Received: March 7, 2018

Accepted: May 6, 2018

Published: May 9, 2018

Copyright $(9) 2018$ by authors and Scientific Research Publishing Inc. This work is licensed under the Creative Commons Attribution International License (CC BY 4.0).

http://creativecommons.org/licenses/by/4.0/

\begin{abstract}
In Senegal, rock mechanic studies began in last four years and were a very new engineering domain. So, the first stage is to characterize geological materials. It is on this way that this work is done. This paper analyzes geomechanical parameters of sandstones of Dindifélo and basalt of Bafoundou belonging to the Proterozoic rocks domain of eastern Senegal. By Rock Mass Rating (RMR) and Geological Strength Index (GSI), sandstones of the Dindifello Cliff show fair to poor characteristics while basalts of the hills of Bafoundou are fair quality. In addition to the qualities of rock mass, Young moduli, uniaxial compressive strengths and tensile strength of rock mass are also defined using Rock Quality Designation (RQD) GSI, RMR. Hoek-Brown parameters m and a, depend both on the fracturation and the content fine in the rock. Values of mechanical parameters are different when deduced from RMR, GSI and from intact rock laboratory test. Those differences are due to variables taken account. The variation depends also on the quality of the rock. Statistical analysis shows possible unstabilities which depend on rock mass parameters but with acceptable probability of failure. Probability of failure is the highest when deducing from Mohr criterion than from Hoek-Brown criterion.
\end{abstract}

\section{Keywords}

Geomechanical Classifications, Sandstones, Basalt, Dindifélo, Mako

\section{Introduction}

Sedimentary rock formations of eastern Senegal belong to the Segou-Madina Kouta basin. They are Neoproterozoic to lower Paleozoic age. These rocks out- 
crop like Cliff throughout the border between Senegal and Guinea. The geomorphology of this border constitutes an obstacle of integration in West Africa because of the difficulty that this Cliff caused to the traffic between countries. These formations are deposited on the diphasic volcanic of the Paleoproterozoic of the Kedougou-Kenieba inlier. The most important volcanic facies corresponds with the basalts which appear like hill. The lack of knowledge of the behavior of these Cliffs is also a danger for the local population and mostly for tourist because of the possible unstabilities it is exposed. Recent studies give laboratory parameters that are UCS and intact rock Young moduli. So, it is necessary to know the behavior of the geotechnical facies that constitute this Cliff (red, white, purple and with intercalation of pelites). Works carried on the sector of Senegal Oriental consist of geological and mineral studies and are done since 1980 by Cheikh Anta Diop University team. These studies permit now a good knowledge of the sector. It is established that basalts are essentially the banking of minerals ore body and sandstone corresponds with cliff between Senegal and Guinea. For the hill of basalts, the lack of knowledge is a limit of minerals exploitation because basalts are the banking of minerals and a public menace. So, this work will permit to define mechanical parameters of these formations and to know their impact on rock behavior. The Proterozoic basalts and sandstone look hard. But how are they when contain fine? When contain pelit, sandstones become the most weak. These parameters impact the quality of the rock mass. After studding the geological and structural aspects of these very formations, we are going to talk about the parameters deduced from the GSI and RMR rock mass classifications and which are served to design slope on rock engineering. So, are used classifications impacted characters of the rock? Did it impact the intrinsic rock mass parameters? The last stage of this work consists in using the applications.

\section{General Framework}

\subsection{Geographical and Geological Framework}

The sedimentary cover that deposed on the Birimian of Senegal (part of West Africa Craton) match to the Neoproterozoic rock formation of Segou-Madina kouta basin. In Senegal, the Birimian corresponds with two supergroup. The Mako Supergroup is represented by volcanic facies essentially. The magmatic rocks vary from ultrabasic to hyperquartzic terms and are dominated by basaltic rocks. There are also volcanoclastic terms. The supergroup of Diale-Dalema corresponds with volcanic-sedimentary, sedimentary and volcanic rocks. It is characterized by an intensive tectonic.

The Segou-medina kouta basin, extend over $30,000 \mathrm{~km}^{2}$, outcrops like a strip along the border between Senegal and Guinea. This very basin is subdivided into two Supergroups [1] [2]; Supergroup I and Supergroup II. These supergroups are subdivided into five formations for the supergroup I and two formations for the Supergroup II: 
-The formations of Supergroup I are essentially composed by sandstones, pelites and siltstones. The difference between the constituents of the formations depends on the percent of each sediment deposit. These formations are Neoproterozoic.

-The formations of Supergroup II are deposited on the first one by Eocambrian conglomerate tilites [3]. The other part of the deposition is composed by sandstones, siltstones and carbonates. Sometimes, parts of clay are present. The rocks of this Supergroup are laminated and are Low Paleozoic.

In Senegal, rocks belonging to this basin correspond with outcrops of the Supergroup I. Along the border between Senegal and Guinea, on the area of Segou-Dindifélo-Pellel (Figure 1(a)), the outcrops are essentially represented by rocks of the formation of Dindifélo. So, it is essentially characteristics of this formation that are studied in this paper.

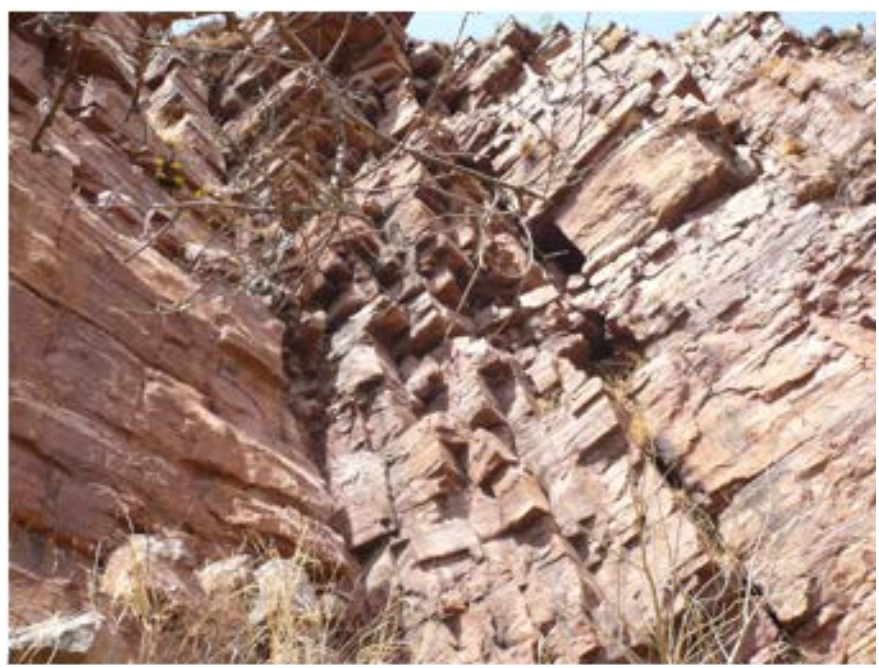

(a)

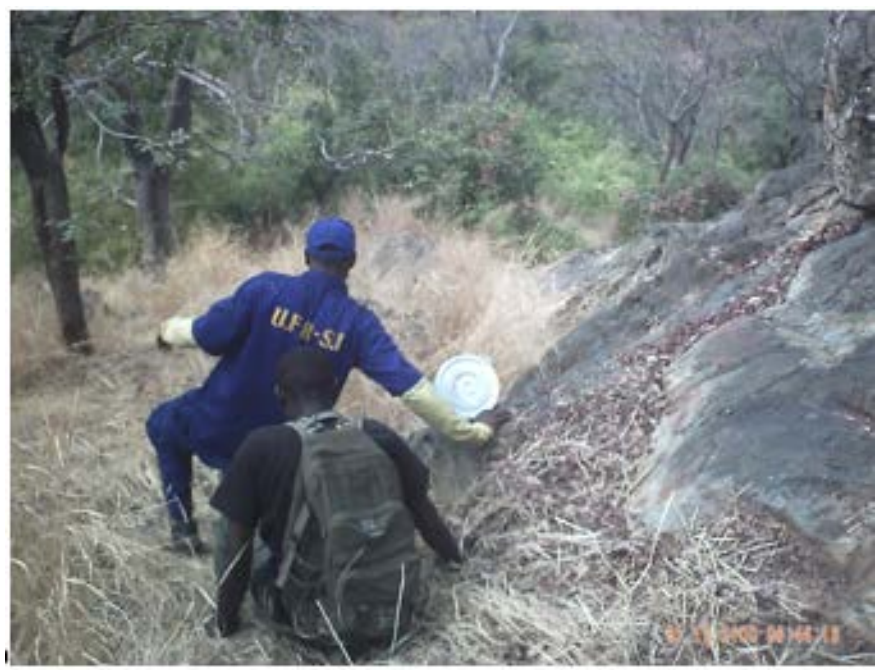

(b)

Figure 1. Samples of rock mass cliff of Segou (a) and basaltic rock mass of Mako (b). 


\subsection{Petrographic and Structural Aspect}

The Segou area of Segou-Madina kouta basin is constituted by detritic rocks essentially and is deposited on the volcanic area of the Kédougou-Kéniéba inlier. The west part of this inlier corresponds with the Mako supergroup and is dominated by basaltic volcanism. The lithology is composed by a complete magmatic sequence that varies from ultrabasic to acid rocks and from plutonic to volcanic terms. The detritic facies of the basin present variable size grains from sand size to silt and pelites. The lithology is composed by sandstones essentially and sandstones alternating with pelites (Figure 1(a)).

The Lithostratigraphy of the Mako supergroup is composed by two entities. The lower unit corresponds with pillow lavas (Figure 1(b)) associated to pyroxenites, volcanoclastes, metamorphic sediments and prasinites. The upper unit is constituted by dyke of andesite, discordant pluton of gabbro and dykes of lamprophyre. There are also acid rocks.

From Segou to Dindifélo, the cliff is composed by sandstones alternating pelites and spread on three members. The member M1 is composed by thin beds of fine sandstones alternating with red pelites. This member is deposited on limestone of Pellel. On the M1 member is deposited the M2 constituted by coarse sandstones alternating with red pelites. The last member M3 of this formation corresponds with ruiniform sandstones.

Structurally, the Senegalese side of the Segou-Madina kouta basin is composed by three directions of discontinuities which are NE, N and NW. These discontinuities are represented by a dense network of diaclases and locally there are some faults.

The structural aspect of the Mako area is very complex. It depends on the shear zones and magmatic crystallization phenomena. All kind of discontinuities present in the Senegalese side of the Kedougou-Kenieba inlier can be noted on the basalts of this domain. Discontinuities found are or not filled and oriented in all directions because of the multiple orogenesis which affect this domain. These orogenesis have also aftereffect which make the tectonic of this area more complex. Despite this complexity, the tectonic of this area shows three preferential directions of fractures: the NNE to NE direction, the NNW to NW direction and the $\mathrm{N}$ direction. In addition to these brittle deformations, ductile ones are also noted. They are essentially represented by fold designations.

\section{Methodological and Theoretical Approach}

The index RMR of Bieniawski is defined using six variables [3] determined in the field or at laboratory. They are:

-Uniaxial compressive strength;

-Rock Quality Designation (RQD);

-Spacing of discontinuities;

-Nature of discontinuities; 
-Hydraulic conditions;

-Factor of correction.

Equivalent parameters of the rock masses would be determined. Indeed, the geomechanical properties of rock masses are determined by deduction on the geomechanical table of RMR or calculated by empirical relations taking account the RMR index.

$$
E_{m}=E_{i}\left[10^{0.0186 \mathrm{RQD}-1.91}\right]
$$

$E_{m}$ is the Young modulus of rock mass.

There are on the literature some empirical functions established in order to calculate equivalent cohesion, friction angle and young moduli. These correlating functions concerned parameters and RMR index.

When RMR $>50$

$$
E_{m \dot{e}}(\mathrm{GPa})=2 \mathrm{RMR}-100
$$

For $\mathrm{RMR}<50$

$$
E_{m e ́}(\mathrm{GPa})=10^{[\mathrm{RMR}-10] / 40}
$$

$E_{m e}$ is the equivalent Young modulus.

For the determination of equivalent friction angle [4], following relation will be used

$$
\varphi_{\dot{e}}=0.5 \mathrm{RMR}+8.3 \pm 7.3
$$

$\varphi_{e}$ is the equivalent angle of friction.

For calculation of the equivalent cohesion, the used model is

$$
c_{\dot{e}}(\mathrm{kPa})=5 \mathrm{RMR}
$$

$c_{e}$ is the equivalent cohesion.

Equivalent uniaxial compressive strength $\left(R_{c e}\right)$ and tensile strength $\left(R_{t e ́}\right)$ are deduced from equivalent cohesion by following functions

$$
\begin{aligned}
R_{c \dot{e}} & =2 c_{\dot{e}} \cos \varphi_{\dot{e}} /\left(1-\sin \varphi_{\dot{e}}\right) \\
R_{t \dot{e}} & =2 c_{\dot{e}} \cos \varphi_{\dot{e}} /\left(1+\sin \varphi_{\dot{e}}\right)
\end{aligned}
$$

Determination of geological strength Index (GSI) is done using [3] [5] [6]:

-The SCR (Surface Condition Rating) characteristic of the surface of discontinuities. His estimation depends on the alteration of discontinuities $R_{w}$, the rugosity of the walls of fractures $R_{r}$ and the filled of discontinuities $R_{f}$ It is calculate by the function

$$
\mathrm{SCR}=R_{w}+R_{r}+R_{f}
$$

-The SR (Structure Rating) characterizes the bloc sizes [3] [6] [7]. The SR depends on the density of joints. On view of the principle defined above, these parameters depend largely on the stage of fracturation of the rock.

Hoek-Brown failure criterion is used up to this paper. Parameters of this fail- 
ure criterion [7] [8] are deduced from the GSI. His formulation is

$$
\sigma_{1}=\sigma_{3}+\left[m \sigma_{c} \sigma_{3}+\sigma_{c}^{2} s\right]^{a}
$$

$m$ is a constant defined the cohesion of the rock. For intact rock, it is called $m_{i}$ and for fractured rock it is noted $m_{b}$. They are linked by the following function

$$
m_{b}=m_{i} \cdot \mathrm{e}^{(\mathrm{GSI}-100) / 28}
$$

$s$ and a depend on crack intensity of the rock mass.

The tensile strength of a rock mass which can be described than responding to Hoek-Brown [9] failure criterion is

$$
\sigma_{t}=0.5 \sigma_{c}\left(m_{b}-\sqrt{m_{b}^{2}+4 s}\right)
$$

$a$ and $s$ depend on the value of GSI :

- GSI $>25$

$$
a=0.5 \text { and } s=\exp ((\mathrm{GSI}-100) / 9)
$$

- GSI $<25$

$$
s=0 \text { and } a=0.65-\mathrm{GSI} / 200
$$

\section{Rock Parameters}

\subsection{Field Parameters}

Spacing and Opening of discontinuities vary from a facies to another [3]. Spacing's vary between 17 and $20 \mathrm{~cm}$ for fractures located on the beds of sandstones and are less than $12 \mathrm{~cm}$ for fractures located on pelites. Spacing of stratification varies also with the lithological succession concerned. It is low for the first member M1 that is rich at pelite and high part of the member that are essentially composed by sandstones. The average spacing is around of $3 \mathrm{~cm}$ in the member $\mathrm{M} 1$ and 37 to $160 \mathrm{~cm}$ for the member M2.

The fractures present some opening of $0.2 \mathrm{~cm}$ up to $3 \mathrm{~cm}$ locally. At the interface of stratification, apparent opening can be very high because of probable dissolution of fine deposits like pelites with an average value of $4 \mathrm{~cm}$. the discontinuities are not fielded and their wall present low values of joint roughness coefficient (JRC) less than 2. JRC of stratifications varies on large ranges from the smooth (values of 0 to 2 ) to the rough (14 to 16) because of the heterogeneous of beds caused by the presence of pelites or undulation. Spacing and aperture of discontinuities vary from a locality to another on the basalts of Bafoundou. Lower values of aperture are characteristic of cracks. They vary between 0 and 0.5 centimeters. For tension cracks filled with quartz, aperture can be high and vary around 4 centimeters. Some of the cracks are filled with secondary crystallization. Spacing of discontinuities varies between 8 centimeter and 30 centimeters. When considering separately discontinuities, average spacing's are 6.5 to 10 centimeters for tension cracks, 20 centimeters for unfilled fractures. Somewhere, rock is massive and present only superficial tension cracks. Rugosity of discon- 
tinuities is low to fair and depends on the type of discontinuity. So, average value of rugosity (JRC) is defined for different kind of joints. It is 1 for cracks and filled fractures, 3 for tension cracks, 4 for others cracks and unfilled fractures. These values show that brittle structures are smooth. For cracks and unfilled fractures JRC value is less than 1 characteristic of very smooth discontinuities. For tension cracks filled with quartz, JRC is less than 4 and that significant they are smooth. Unfilled fractures are most rough quality. The value of JRC is more than 4 . They are less smooth than others.

\subsection{Laboratory Characterization}

Laboratory tests [3] gave some values of uniaxial compressive strength of 62.8 $\mathrm{MPa}$ for the red sandstones, 73.3 MPa for the white sandstones, 50.3 MPa for the purple sandstones and 39.8 MPa for sandstones with intercalation of pelites. The same tests permit deduction of Young moduli of these rocks. It varies also from a facies to another. It is $8000 \mathrm{MPa}$ the red sandstones, 10,540 MPa for white sandstones, $7500 \mathrm{MPa}$ for purple ones and 2900 for ones with intercalation of pelites. The rock quality designation (RQD) is calculated by using the scanline survey method defines on the field because of the absence of core. The RQD varies between $88 \%$ and $90 \%$.

Basalts studies are relatively same except their proximity of the shear zone. On the field, the one that are near these events are more affecting. These tests permit to determine Young moduli and uniaxial compressive strengths (MPa). Uniaxial compression strengths are 85 for healthy basalt, 86.7 for basalts with unfilled discontinuities, 75 for basalts with tension cracks, 64.4 for basalts with fractures filled with calcite, chlorite and epidote. Young moduli are 13,351 for the healthy basalts, 12,566 for the basalts with unfilled discontinuities, 12,300 for the basalts with tension cracks, 6647 for the basalts with fractures filled with calcite, chlorite and epidote and, at least, 9,833 for basalts with multiple fractures.

\section{Rock Mass Analysis}

\subsection{Use of RMR Index for Rock Analysis}

Rock index RMR is defined for each facies (Table 1). This index is 42 for red and white sandstones, 32 for purple sandstones and 21 for facies with intercalation of pelite. Concerning the rock mass class, red and white sandstones belong to class III (fair quality), purple sandstones are class IV (poor quality) and facies with intercalation of pelite are class V (very poor quality). In addition to these characteristics for which the Bieniawski table is used, the Young moduli of the rock mass are calculated using empirical functions.

The Young moduli of rock mass determined by this Equation (1) is $4375 \mathrm{MPa}$ for the red sandstones, $5765 \mathrm{MPa}$ for the white sandstones, $4102 \mathrm{MPa}$ for the purple sandstones and $2079 \mathrm{MPa}$ for the sandstones with intercalation of pelites (Table 1(a)). 
Table 1. (a) Parameters of sandstones deduced from the RMR; (b) Parameters of basalts deduced from the RMR.

(a)

\begin{tabular}{|c|c|c|c|c|}
\hline Parameters & Red sandstones & White sandstones & Purple sandstones & $\begin{array}{c}\text { Sandstone with } \\
\text { intercalation of pelites }\end{array}$ \\
\hline$E_{m}(\mathrm{MPa})$ & 4375.2 & 5765 & 4102 & 2079 \\
\hline RMR & 42 & 42 & 32 & 21 \\
\hline$c(\mathrm{kPa})$ & $200-300$ & $200-300$ & $100-200$ & $100-200$ \\
\hline$\varphi\left({ }^{\circ}\right)$ & $25-35$ & $25-35$ & $15-25$ & $15-25$ \\
\hline$c_{\hat{\varepsilon}}(\mathrm{kPa})$ & 210 & 210 & 160 & 105 \\
\hline$\varphi_{\dot{\varepsilon}}\left({ }^{\circ}\right)$ & 29.3 & 29.3 & 16 & 18.8 \\
\hline$E_{m e}(\mathrm{GPa})$ & 6.3 & 6.3 & 3.55 & 1.88 \\
\hline$R_{c e}(\mathrm{kPa})$ & 717 & 717 & 424.6 & 293.3 \\
\hline$R_{t e}(\mathrm{kPa})$ & 245.9 & 245.9 & 241 & 150 \\
\hline
\end{tabular}

(b)

\begin{tabular}{|c|c|c|c|c|c|}
\hline Parameters & $\begin{array}{l}\text { Healthy } \\
\text { basalts }\end{array}$ & $\begin{array}{l}\text { Unfilled } \\
\text { fractures }\end{array}$ & $\begin{array}{l}\text { Tension } \\
\text { cracks }\end{array}$ & $\begin{array}{l}\text { Fractures filled with } \\
\text { calcite, epidote, chlorite }\end{array}$ & $\begin{array}{l}\text { Multiples } \\
\text { fractures }\end{array}$ \\
\hline$E$ & 13,351 & 12,566 & 10,300 & 6647 & 9833 \\
\hline$E_{m}(\mathrm{MPa})$ & 4390 & 4132 & 3387 & 2186 & 3233 \\
\hline $\mathrm{RMR}_{\mathrm{sec}}$ & \multicolumn{5}{|c|}{54} \\
\hline$c(\mathrm{kPa})$ & \multicolumn{5}{|c|}{$200-300$} \\
\hline$\varphi\left({ }^{\circ}\right)$ & \multicolumn{5}{|c|}{$25-35$} \\
\hline$c_{e}(\mathrm{kPa})$ & \multicolumn{5}{|c|}{270} \\
\hline$\varphi_{\varepsilon}\left({ }^{\circ}\right)$ & \multicolumn{5}{|c|}{35.3} \\
\hline$E_{m e}(\mathrm{GPa})$ & \multicolumn{5}{|c|}{8} \\
\hline$R_{c e ́}$ & \multicolumn{5}{|c|}{1044} \\
\hline$R_{t e ́}$ & \multicolumn{5}{|c|}{279.3} \\
\hline $\mathrm{RMR}_{\text {humide }}$ & \multicolumn{5}{|c|}{39} \\
\hline$c(\mathrm{kPa})$ & \multicolumn{5}{|c|}{$100-200$} \\
\hline$\varphi\left({ }^{\circ}\right)$ & \multicolumn{5}{|c|}{$15-25$} \\
\hline$c_{\hat{e}}(\mathrm{kPa})$ & \multicolumn{5}{|c|}{195} \\
\hline$\varphi_{e}\left({ }^{\circ}\right)$ & \multicolumn{5}{|c|}{27.8} \\
\hline$E_{m e}(\mathrm{GPa})$ & \multicolumn{5}{|c|}{5.3} \\
\hline$R_{c e ́}$ & \multicolumn{5}{|c|}{646} \\
\hline$R_{t e ́}$ & \multicolumn{5}{|c|}{235} \\
\hline
\end{tabular}

The characterization is done for basalts (Table 1(b)). So, other properties are defined on some targeted samples (healthy samples, filled ones, one fracture, 
multiples fractures). For estimation of the RMR of the rock mass, the hill is considered first to be dry, then afterwards to be wet. For dry rock, RMR has a value of 54 versus 39 for wet rock mass. So, dry basalt is fair quality (class III) and wet basalt is poor quality. But the study rock mass can be considered as wet only during the rainy season. Also, all joints are not connected.

For Young modulus of basalts, it varies locally according the natures of discontinuities present in the domain. So, Young modulus is 4390 for the healthy basalt, 4132 for the basalt with unfilled fractures, 3387 for samples with tension cracks, 2186 when the basalt contain fractures filled with calcite, chlorite and epidote and 3233 when the rock contain several direction of discontinuities.

Comparison between parameters defined by the table and equivalent ones.

As well as for the cohesion than for the friction angle, equivalent values obtained by empirical relations linking these parameters to the RMR index are in the ranges of value determined by using the table of Bieniawski (Table 1).

Whenever, concerning the Young modulus of rock mass, it is deduce from the Young modulus of the intact rock or from the value of RMR. The study rock masses can be divided into two classes. The red and white sandstones are fair qualities and the purple and the ones with intercalation of pelites are poor qualities. For the first group, the equivalent modulus is higher than the one determined using laboratory results. For the second group, the equivalent modulus is less than the one defined by laboratory tests.

For basalt of Precambrian, equivalent Young modulus defined using RMR value is higher than value determined using the results of uniaxial compression tests. In another point of view, this parameter is higher for dry basalts than for wet ones.

Equivalent cohesion is contained in the range of value defined in the table of Bieniawski. This is valid for both dry rock mass as wet one. So, the correlation seems to be acceptable when defining cohesion for rocks.

For equivalent friction angle, calculated value based on the RMR is higher than the upper limit value of the range of Bieniawski both for wet as dry rocks. The difference between calculate value and the upper limit value is more marked when the rock mass is wet.

\subsection{Use of GSI Classification for Characterization of Rock Masses}

Using SCR and SR values, table of Hoek is modified by Ulusay and Sonmez (Figure 2) permit to deduce the Geological Strength Index. Now, GSI summarized in Table 2(a) are obtained. Red sandstones present GSI of 45, for white sandstones we have GSI of 51 and 42 for the purple ones. The worst value of GSI corresponds with the facies with intercalation of pelites which is 20. For GSI classification, all facies are fair quality except the one with intercalation of pelite which is very poor quality.

The GSI is also defined for basalt (Table 2(b)) with the same considerations 
Table 2. (a) Parameters deduced from the GSI; (b) Parameters deduced from the GSI.

(a)

\begin{tabular}{ccccc}
\hline Parameters & Red sandstones White sandstones & $\begin{array}{c}\text { Purple } \\
\text { sandstones }\end{array}$ & $\begin{array}{c}\text { Sandstone with intercalation } \\
\text { of pelites }\end{array}$ \\
\hline GSI & 44 & 51 & 42 & 20 \\
$\boldsymbol{s}$ & 0.002 & 0.004 & 0.002 & 0.000 \\
$\boldsymbol{a}$ & 0.50 & 0.50 & 0.50 & 0.55 \\
$\boldsymbol{\sigma}_{c m}(\mathrm{MPa})$ & 5.62 & 10.36 & 5.5 & 2.52 \\
$\boldsymbol{m}_{\boldsymbol{i}}$ & 19 & 19 & 19 & 9 \\
$\boldsymbol{m}_{\boldsymbol{b}}$ & 2.57 & 3.30 & 2.39 & 0.52 \\
$\boldsymbol{\sigma}_{\mathbf{t}}(\mathrm{MPa})$ & -0.049 & -0.089 & -0.042 & 0.000 \\
\hline
\end{tabular}

(b)

\begin{tabular}{|c|c|c|c|c|c|}
\hline Parameters & $\begin{array}{c}\text { Healthy } \\
\text { basalts }\end{array}$ & $\begin{array}{l}\text { Unfilled } \\
\text { fractures }\end{array}$ & Tension cracks & $\begin{array}{l}\text { Fractures filled with } \\
\text { calcite, epidote, chlorite }\end{array}$ & $\begin{array}{l}\text { Multiples } \\
\text { fractures }\end{array}$ \\
\hline GSI & \multicolumn{5}{|c|}{47} \\
\hline$s$ & \multicolumn{5}{|c|}{0.003} \\
\hline$a$ & \multicolumn{5}{|c|}{0.5} \\
\hline$m_{i}$ & \multicolumn{5}{|c|}{25} \\
\hline$m_{b}$ & \multicolumn{5}{|c|}{3.8} \\
\hline Rc & 85.0 & 86.7 & 75.0 & 64.4 & 93,1 \\
\hline$\sigma_{t}$ & -0.067 & -0.068 & -0.059 & -0.051 & -0.073 \\
\hline
\end{tabular}

than for determination of RMR. So, value of GSI for this rock is 47 and belongs to the fair quality rocks.

In laboratory, tests done gave some values of uniaxial compressive strength of 62.8 MPa for red sandstones, 73.3 MPa for white sandstones, 50.25 MPa for purple sandstones and 39.8 MPa for the facies with intercalation of pelites. Based on the Equation (10) tensile strengths are calculate and results are summarized in Table 2(a).

Red, white and purple sandstones are sandstones senso stricto because of the dimensions of the components. So, the mi value deduced from the Hoek table for intact rock mass is 19. In opposite of these three facies, sandstones with intercalation of pelites present granulometric characteristics that bring them closer to the siltstones. So, by Hoek table, their mi is 9. Constants mb characteristic of fractured rock masses are calculated by relation (9) and values summarized in Table 2(a). It is 2.57 for the red sandstones, 3.3 for the white sandstones and 2.39 for the purple sandstones. The facies with intercalation of pelites shows a $\mathrm{mb}$ of 0.52 . This parameter is as low as the rock is poor quality.

For those basalts, the reference fracturation parameter mi is 25 after the table of Hoek. More the rock is altered, more the value of $\mathrm{m}$ corresponding to $\mathrm{mb}$ fall 
down (Table 2(b)). So, for fractured basalts of Precambrian, the mb is equal to 3.8 .

\subsection{Statistical Analysis of Wedge Unstabilities}

Diagrams represented (Figures 3-5) show the domains of unstabilities of the rock wedges according to mechanical and geometrical parameters. These domains are colored in red and surround for cohesion (Figure 3(a)) and friction angle (Figure 3(b)) a large gam of values with low frequencies when compared to whole relative frequency of the corresponding value. For slope angle, failed wedges appear for high angle, superior to $67^{\circ}$ (Figure $3(\mathrm{c})$ ). For the corner wedge slope, instabilities are produced when lengths line of intersection of the

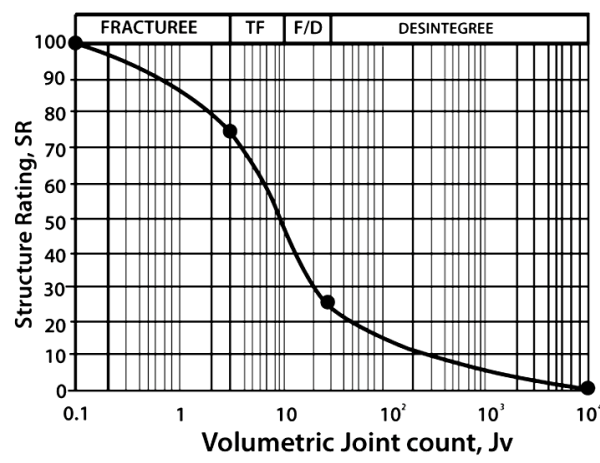

Figure 2. Table of determination of SR [10].

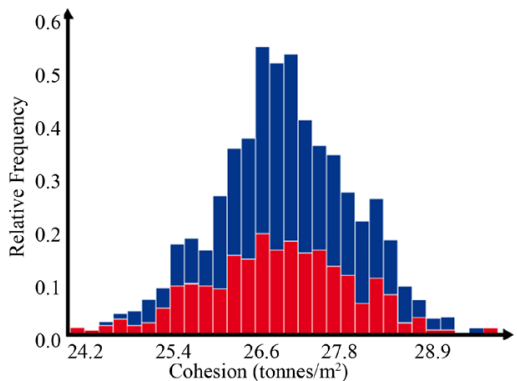

Mean=27; Min=24.02; $\operatorname{Max}=29,93 ;$ S.d. $=0.9616$

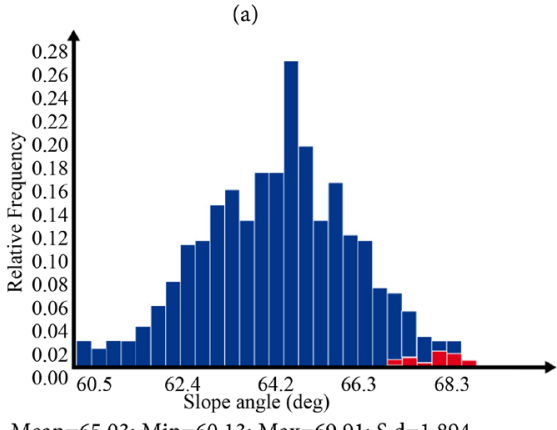

Mean=65.03; $\operatorname{Min}=60.13 ; \operatorname{Max}=69.91 ; \mathrm{S} . \mathrm{d}=1.894$

(c)

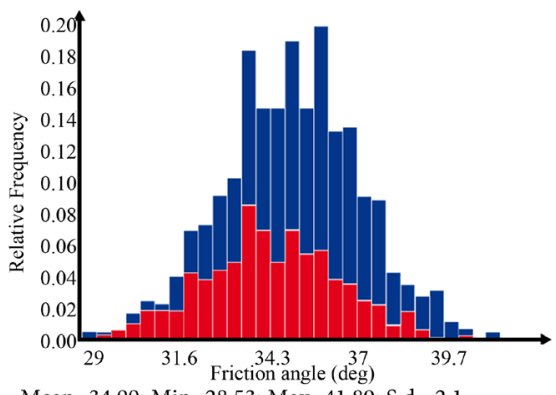

Mean=34.99; $\operatorname{Min}=28.53 ; \operatorname{Max}=41.89 ;$ S.d. $=2.1$

(b)

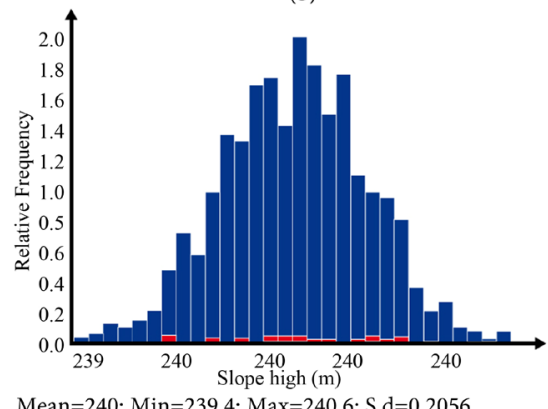

(d)

Figure 3. Distribution of parameters (a) cohesion; (b) friction angle; (c) slope angle; (d) slope high) for basalt hill of Bafoundou-Badian (East Senegal) using Roc Plane. (Red: unstable wedge; blue: stable wedge). 


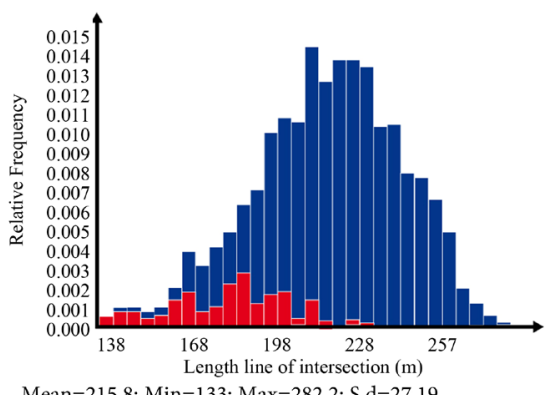

Mean=215.8; Min=133; Max=282.2; S.d=27.19

(a)

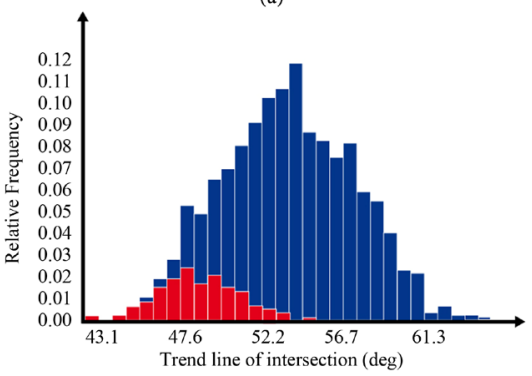

Mean=53.64; $\operatorname{Min}=42.29 ; \operatorname{Max}=65.09 ; \mathrm{S} . \mathrm{d}=3.734$

(c)

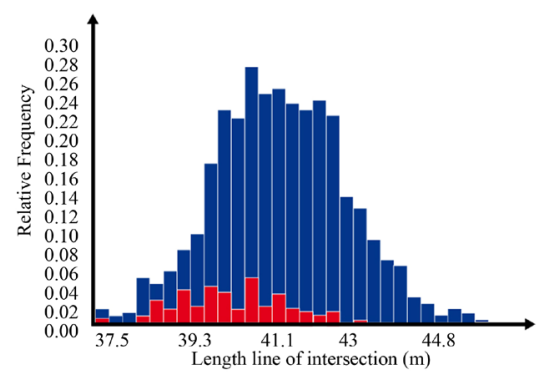

Mean=41.3; $\operatorname{Min}=37.16 ; \operatorname{Max}=46.36 ; \mathrm{S} . \mathrm{d}=1.464$

(b)

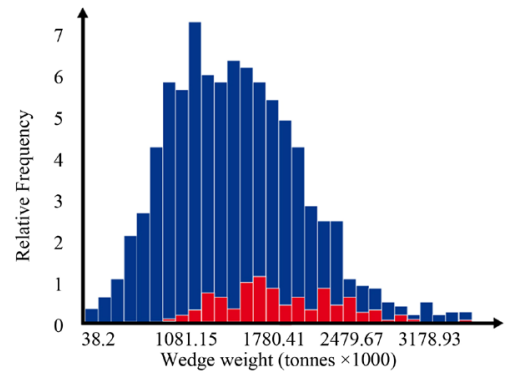

Mean=1636; $\operatorname{Min}=265.4 ; \operatorname{Max}=3762 ;$ S.d. $=606.4$

(d)

Figure 4. Distribution of parameters (a) Length line of intersection; (b) Plunge line of intersection; (c) Trend line of intersection; (d) Wedge weight for basalt hill of Bafoundou-Badian (East Senegal) using Swedge. (Red: unstable wedge; blue: stable wedge).

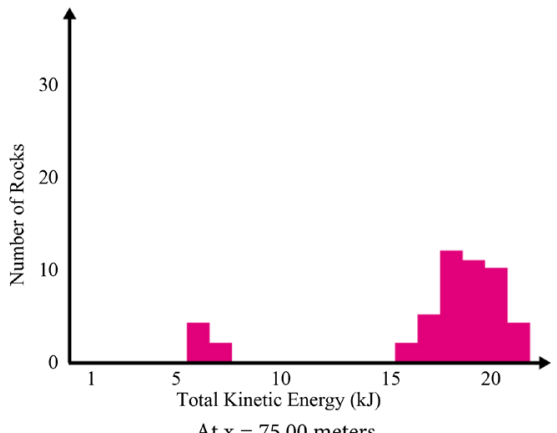

At $\mathrm{x}=75.00$ meters

(a)

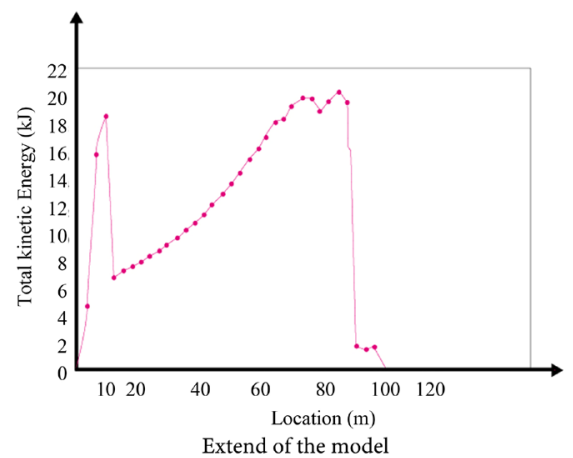

(b)

Figure 5. Distribution of Total kinetic energy (a) and it envelop versus location for sandstones of Dindifello (b) using RocFall.

two discontinuities forming the block are low values. So, the limit value is around 224 meters (Figure $4(\mathrm{a})$ ). For plunge angle of line of intersection (Figure 4(b)) between $37^{\circ}$ and $43^{\circ}$, rock blocks may be instable when consisting of slide between two discontinuities. Trend line of intersection (Figure 4(c)), when belongs the interval $43^{\circ}-53^{\circ}$, caused also instabilities of wedge. The modal value of trend line of intersection is $47.6^{\circ}$ while the one of plunge line of intersection is $37.82^{\circ}$. For the Dindifello blocks where the high of slope referred to the ground is around 225 meters an important energy is developed at 75 meters from de Cliff. This length corresponds with the point where rock blocks touch the ground (Figure $5(\mathrm{~b})$ ). The modal energy at $18.5 \mathrm{~kJ}$ per block will be well 
taken account for best protection of the sites (Figure 5(a)). For One planar failure, probability of failure (PF) is $41 \%$ for Mohr-Coulomb criterion and $1.7 \%$ for Hoek-Brown criterion. For corner failure type, PF is around of $10 \%$ and characterize best the field observations.

\section{Conclusion}

The Dindifélo area (in Senegal) is characterized by his lithology represented by sandstones. Sometimes, these sandstones present some portions of pelites. Structurally, three families of discontinuities NE, N and NW are represented. Using RMR or GSI rock mass classifications, the quality of the rock depends on the content pelites. Using Hoek-Brown criterion, the factors $a$ and $m$ are impacted by the fractures of the rocks and by his content fine particles. Their values decrease with increase of fracturation density and content pelites. Values obtained for mechanical parameters depend on the used model or classifications. So, tensile strength, compression strength and others intrinsic parameters differ when deduced from GSI, from RMR or from correlation using laboratory test. Those differences are caused by the differences in the elements taken account in these cases. The relation between Young moduli of rock mass deduced from laboratory test and field study depends on the rock quality. Best correlation for equivalent cohesion and friction angles are obtained for basalt when it is wet. In this case, tensile strength calculated with RMR is higher than the ones calculated by GSI. Using RocPlane, Swedge and RocFall for statistical analysis, it is noted that wedge formed by discontinuities is unstable with acceptable probability of failure. Those unstabilities depend on variable parameters such as cohesion, friction angle, slopes and parameters of line of intersection of discontinuities. Establishment of a behavior model would permit best knowledge's of the hills and cliffs behavior. Probability of failure is less when Hoek-Brown criterion is used. This feels better field observation.

\section{Acknowledgements}

Authors would acknowledge to Professor Meissa Fall (Geotechnical Professor at Université de Thiès) for his guidance for this work. God has mercy on his soul. Acknowledge to Mamadou Koné (Malian senior mine) for giving us applications.

\section{References}

[1] Delor, C., Couëffé, R., Goujou, J.-C., Diallo, D.P., Théveniaut, H., Fullgraf, T., Ndiaye, P.M., Dioh, E., Blein, O., Barry, T.M.M., Cocherie, A., Le Metour, J., Marte-let, G., Sergeev, S. and et Wemmer, K. (2010) Notice explicative de la carte géologique à 1/200,000 du Sénégal, feuille Saraya-Kédougou Est. Ministère des Mines, de l'industrie, de l'Agro-Industrie et des PME, Direction des Mines et de la géologie, Dakar. underground.

[2] Théveniaut, H., Ndiaye, P.M., Buscail, F., Couëffé, R., Delor, C., Fullgraf, T. and Goujou, J.-C. (2010) Notice explicative de la carte géologique du Sénégal oriental à 
1/500,000. Ministère des Mines, de l'Industrie, de l'Agro-Industrie et des PME, Direction des Mines et de la Géologie, Dakar.

[3] Sarr, D. (2012) Propriétés géomécaniques des basaltes en pillow de Mako et des roches grésopélitique de Ségou (boutonnière de Kédougou-Kéniéba) au Sénégal. Thèse de Doctorat de l'UCAD, Dakar., 248 p.

[4] Gunzburger, Y. and Merrien-Soukatchoff, V. (2002) Caractérisation mécanique d'un grand versant rocheux instable au moyen d'un système RMR-Cas de la Clapière (Alpes françaises). Symposium International PARAM 2002, Sep. 2002, Paris, France, 541-548. <ineris-00972375>

[5] Marinos, P. and Marinos, E.H. (2005) The Geological Strength Index: Application and Limitation. Bulletin of Engineering Geology and the Environment, 64, 55-65. tps://doi.org/10.1007/s10064-004-0270-5

[6] Russo, G. (2007) Integrating the GSI and RMI System. Tunneling and Underground Space Technology, $9 \mathrm{p}$.

[7] Hoek, E. and Kartzulovic, A. (2000) Rock Mass Properties for Surface Mines. In: Hustralid, W.A., McCarter, M.K. and van Zyl, D.J.A., Eds., Slope Stability in Surface Mining, Society for Mining, Metallurgical and Exploration (SME), Littleton, Colorado.

[8] Hoek, E. (1990) Estimating Mohr-Coulomb Friction and Cohesion Values from the Hoek-Brown Failure Criterion. International Journal of Rock Mechanics and Mining Sciences \& Geomechanics Abstracts, 27, 227-229. https://doi.org/10.1016/0148-9062(90)94333-O

[9] Hoek, E. and Brown, E.T. (1997) Practical Estimates of Rock Mass Strength. The International Journal of Rock Mechanic and Mining Sciences, 34, 1165-1186. https://doi.org/10.1016/S1365-1609(97)80069-X

[10] Sonmez, H. and Ulusay, R. (1999) Modification to the Geological Strength Index (GSI) and Their Applicability to Stability of Slopes. International Journal of Rock Mechanics and Mining Sciences, 36, 743-760. https://doi.org/10.1016/S0148-9062(99)00043-1 